\section{Demonstration and Evlauation of Enset Corm (Ensete venrticosum) Based Oxen Fattening in Kachabira and Lemu Districts, Southern Ethiopia}

\section{Deribe Gemiyo $^{1 *}$, Zekarias Bassa ${ }^{1}$ and Tesfaye Alemu ${ }^{2}$ \\ ${ }^{1}$ Southern Agricultural Research Institute (SARI), Areka, Ethiopia}

${ }^{2}$ Oromiya Agricultural Research Institute (OARI), Adami Tulu Agriculutrual Research Centre, Ziway, Ethiopia

\begin{abstract}
A study was conducted to demonstrate and evaluate effects of enset corm (root) supplementation for oxen fed on locally available forage sources under farmer's management at Kachabira and Lemu districts, southern Ethiopia. $3 \mathrm{~kg}$ concentrate mixtures were prepared from wheat bran (86.5\%), noug cake (Gizotia abisynnica) $13 \%$ and salt $(1 \%)$ were offered for all animals across farmers. Enset corm offered based on body weight, $1.5-2 \mathrm{~kg}(0.5-1 \%)$ DM basis was offered per head per day as supplements and farmers were considered as replicates. The results indicated that on average, the overall weight change is $81.1 \mathrm{~kg}$ per head over the fattening period, 90 days. Oxen supplemented with enset corm gained higher $(p<0.05)$ weight at Kachabira compared to those at Lemu. In similar way, an ox fattened at Kachabira is signficaly higher final weight compared to Lemu. The overall mean weight ( $354 \mathrm{~kg} / \mathrm{head})$ and the overall gain ( $900 \mathrm{~g} / \mathrm{head} /$ day), averaged by locations, indicated that fattening is promising for farmers who fatten animals using enset corm as supplements. On thirteen day, $45^{\text {th }}, 60^{\text {th }}, 75^{\text {th }}$ and $90^{\text {th }}$ days oxen at Kachabira was significantly $(p<0.05)$ higher compared to Lemu. There is an increasing trend in weight gain in both locations; the increaemnt rate was higher in Kachabira than Lemu district. It could be concluded that strategic supplementation and fattening of oxen with $500 \mathrm{gm}$ enset corm DM /head/day could be profitable in enset dominant farming systems.
\end{abstract}

*Corresponding author: Deribe Gemiyo, Southern Agricultural Research Institute (SARI), Areka, Ethiopia, Ziway, Ethiopia, E-mail: deribeg2000@yahoo.com

Citation: Gemiyo D, Bassa Z, Alemu T (2021) Demonstration and Evlauation of Enset Corm (Ensete venrticosum) Based Oxen Fattening in Kachabira and Lemu Districts, Southern Ethiopia. J Agron Agri Sci 4: 029.

Received: March 12, 2021; Accepted: March 18, 2021; Published: March 31, 2021

Copyright: ( 2021 Gemiyo D, et al. This is an open-access article distributed under the terms of the Creative Commons Attribution License, which permits unrestricted use, distribution and reproduction in any medium, provided the original author and source are credited.

\section{Introduction}

The livestock sector contributes considerably to Ethiopian economy, yet productivity is not equivocally responded to the livestock popupation of the country. It is eminent that livestock products and by-products in the form of meat, milk, honey, eggs, cheese, and butter supply etc. provide valuable protein that contributes to improve the nutritional status of the peoples of the country [1]. The livestock population of the country was estimated to be about 60 million cattle, 31.3 million sheep, 32.74 million goats, 1.42 million camels in the sedentary areas of the country and poultry estimated to be about 56.87 million [1].

Despite huge potential of livestock population and its diversity, the benefits obtained from the sector are low compared to other African countries and the World standard. Asfaw et al., Berhanu and Pavanello [2-4] reported that on average beef yield per animal is $108.4 \mathrm{~kg}$, which is by far lower than other African countries, $119 \mathrm{~kg}$ for Sudan, $146 \mathrm{~kg}$ for Kenya, $127 \mathrm{~kg}$ for Eastern Africa, $146 \mathrm{~kg}$ for Africa, and $205 \mathrm{~kg}$ for the world. The number of off take rate is also lower than other African countries [1]. Information is available for the Ethiopian Boran breed which widely used for beef in eastern and south eastern part of the country. In southern region, preliminary characterization results confirmed that bull type in southern took long time to attain market weight. Reports indicated that Boran bull performs well under farmers' management condition in southern Ethiopia [5]. There are local central zone cattle populations which perform nearly equivalent beef yield as Boran under well management [6].

To improve beef yield of the region, various research activities have been undertaken in different parts of the country. The recent study on evaluation of feedlot performance of Wolaiyta zebu cattle populations using loaly available energy-rich feeds (taro,enset corm,sugercane and local grasses) at similar ages indicated that the locally avaiable non-conventional feed could subsitutte factory by products for fattening. However, the great majority $(86 \%)$ of livestock feed comes from grazing and crop residues [1] Results from feeding experimant indicated that root crops such as taro and enset corm could potentially susititute factory byproducts and could give organic beef that is preferred as food in the district with special teste and aroma.

Beef cattle research has either been fragmented or less targeted the actual domestic and international market. Conscious of this fact, this national project is prepared to generate feasible technologies to meet the required regional and or international market for beef cattle at different ages for different breeds across agro-ecologies. The study is the continuation of the study conducted by Bassa et al. [7] that confirmed fattening oxen by using local available feed as energy supplement is recommended for areas where local forage is available and enset corm used for supplementation. Shewangizawu et al. [6] also reported that farmers in soutehern Ethiopia used enset parts, sweet potato vines, Taro (Boloso-1) as major supplement for cattle fattening. Therefore, this evaluation was propsed to evaluate enset based oxen fattening using locally available feed resources on beef yield and profitability of fattened animals. 
Citation: Gemiyo D, Bassa Z, Alemu T (2021) Demonstration and Evlauation of Enset Corm (Ensete venrticosum) Based Oxen Fattening in Kachabira and Lemu Districts, Southern Ethiopia. J Agron Agri Sci 4: 029.

\section{Materials and Methods}

\section{Descriptions of the study areas}

Kechabira district of Kembata Tembaro (KT) zone and Hadiya zone are located in south Nations, Nationalities, Peoples Region (SNNPR). Kechabira is situated at the south western parts of the KT zone. The woreda lies between $07^{\circ} 12^{\prime} 30.1^{\prime \prime}-07^{\circ} 17^{\prime} 08.3 \mathrm{~N}$ and $37^{\circ} 47^{\prime} 48-37^{\circ} 50^{\prime} 30.6 \mathrm{E}$ with an altitude of 2400 meters above sea level. Kacha Bira is bordered on the south by an exclave of the Hadiya Zone, on the southwest by the Wolayita Zone, on the west by Hadero Tunto, on the northwest by the Hadiya Zone, on the north by Doyogena and Angacha, and on the east by Kedida Gamela. Kacha Bira has 56 kilometers of all-weather roads and 37 kilometers of dry-weather roads, for an average road density of 310 kilometers per 1000 square kilometers. Lemu is located $230 \mathrm{kms}$ southwest of Addis Ababa. Hadiya zone is among the most extensively cultivated and desnely populated areas of the region. The major crops grown in the area include enset, wheat, barley, tef, faba bean and potato. The farmers also keep different types of livestock including cattle, sheep, goat, equine and poultry. Natural pasture is the main (about 75\%) feed of livestock among Lemu farmers. 50\% of farmers around lemu practice stall feeding. However, less than $0.09 \%$ land is allocated for forage production irrespective of the dairy belt of the region.

\section{Management of experimental animals}

20 beef cattle from Lemu and 16 from Kachabira of similar age were selected for the demonstration and evaluattion. All the experimnetal bulls were given with $3 \mathrm{~kg}$ of concentrate (wheat bran, 60\%; Noug cake, $38 \%$ and salt, $2 \%$ ) as protin suppliment while enset corm was offered based on the body weight ( $0.5-1 \%$ body weight, $1.5-2 \mathrm{~kg} \mathrm{DM} /$ head/day) of the animals. Enset corm meant for experimental animals was offered after slicing and sun drying about 4 to $6 \mathrm{hrs}$ during day time.

\section{Preparation of enset corm for supplementation}

About 0.2 ha land is occupied by enset plant at the majority of farmer's field. There is an enset corm feeding practices to productive animals and fattening oxen among Kachabira and Lemu communities, a total of 32 participants, 16 from each district. Enset corm is chopped into smaller pieces and sun-dried before feeding. About $1.5-2 \mathrm{~kg}$ $\mathrm{DM} /$ head/day enset corm (root) was offered to each ox as energy supplement to fattening animals.

\section{Technology promotion or transfer}

16 participants from Lemu and 16 from Kachabira, a total of 32 ox fattening farmers were involoved in the demonstration of the technology. Farmer's percepetion towards technology, experience shared, the wayforward was recorded and measured accordingly. Filed day was organzied for experience sharing, promoting technology transfer and linking farmers to technology to assess whether adopted or not.

\section{Enset production potential and practices of using enset corm for animals}

About $0.125-0.25$ ha of land of smallholder farmers is occupied by enset production in central south region (Table 1). Farmers used to practice feeding the whole parts or corm of enset root for productive animals, lactating cows and draft oxen as energy source feed. Usually fattening oxen are supplemented initially with few amount and then the amount increases towards the end of the finishing period.

\section{Data analysis}

The data were analyzed using General Linear Model in the procedure of SAS (SAS 2013). Descriptive statistical analysis was used to analyze percentages and socioeconomic parameters. Tukey's test was used to separate means at $\mathrm{p}<0.05$ (Figure 1).

\begin{tabular}{|c|c|c|c|c|c|c|}
\hline Region/zone & \multicolumn{3}{|c|}{ Production in Quintals } & \multicolumn{4}{c|}{ Yield (Quintals/plant) } \\
\hline & Amicho & Kocho & Bulla & Amicho & Kocho & Bulla \\
\hline SNNPR & $17,220,257.28$ & $19,935,121.40$ & $589,993.22$ & 0.22 & 0.26 & 0.01 \\
\hline Guraghe & $831,678.13$ & $865,877.78$ & $33,059.91$ & 0.29 & 0.30 & 0.01 \\
\hline Hadya & $590,662.03$ & $622,029.31$ & $60,567.01$ & 0.22 & 0.23 & 0.02 \\
\hline KT & $17,404.11$ & $24,984.73$ & 947.96 & 0.01 & 0.02 & $*$ \\
\hline Sidama & $9,834,586.49$ & $9,422,838.03$ & $294,456.75$ & 0.25 & 0.24 & 0.01 \\
\hline Gedeo & $3,003,975.22$ & $3,421,855.40$ & $61,909.36$ & 0.39 & 0.44 & 0.01 \\
\hline Wolaiyta & $444,343.35$ & $476,065.62$ & $46,910.55$ & 0.22 & 0.24 & 0.02 \\
\hline Sheka & $931,646.82$ & $2,786,619.67$ & $15,486.49$ & 0.15 & 0.44 & $*$ \\
\hline Keffa & $35,642.69$ & $152,250.85$ & $3,126.45$ & 0.01 & 0.02 & $*$ \\
\hline Gamo Gofa & $45,511.31$ & $78,975.41$ & $5,423.93$ & 0.02 & 0.03 & $*$ \\
\hline Bench Maji & $43,344.01$ & $99,627.53$ & 926.40 & 0.10 & 0.24 & $*$ \\
\hline Yem & - & $168,750.88$ & $6,529.44$ & - & 0.60 & 0.02 \\
\hline Dawuro & $593,772.08$ & $1,087,415.75$ & - & 0.24 & 0.44 & - \\
\hline Konta & $81,552.52$ & $103,337.63$ & - & 0.35 & 0.45 & - \\
\hline Silitie & $446,757.09$ & $304,825.98$ & $23,917.08$ & 0.58 & 0.40 & 0.03 \\
\hline Segene people & $319,381.44$ & $319,669.85$ & $36,731.89$ & 0.39 & 0.39 & 0.05 \\
\hline
\end{tabular}

Table 1: Enset production potential and productivity in SNNPR.

Source: CSA, 2017; KT, Kembata Tembaro zone, *, not estimated 


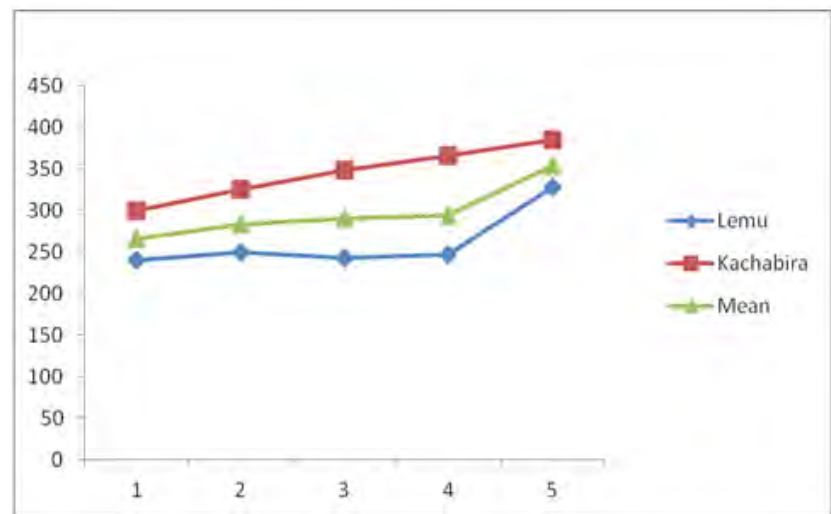

Figure 1: Pattern of weight changes for oxen fattening usieng enset corm in Kachabira and Lemu, southern Ethiopia.

\section{Results and Discussion}

\section{Live weight and average daily gain}

Weight changes and average daily gain of oxen fattening with active participation using enset corm as supplementary feed is presented in table 2 . There was no initial weight vatiations between two the locations and among the fattening oxen. Both locations are known by enset-based wheat farming. Both locations are known by stall feeding (limited movements) of animals with intensive cultivation and extremely high human population pressure. Varaitions across locations and among farmers is unavoidable due to variation in feeed resources and management differences. Weight changes is significantly varied between the locations, oxen fattened at Kachabirra showed significantly $(\mathrm{p}<0.05)$ higher weight changes over Lemu. On average, the overall weight change is $81.1 \mathrm{~kg}$ per head over the fattening period, 90 days. Oxen supplemented at Kachabira gained higher $(\mathrm{p}<0.05)$ weight compared to those at Lemu. In similar way, final weight of oxen fattened at Kachabira was signficaly higher final weight compared to Lemu. The mean weight (354 kg/head) and the overall gain, averaged by locations, indicated that oxen fattened using enset corm gained $900 \mathrm{~g}$ per head/day, which is promising for smallholder farmers who fatten animals using enset corm as supplements. All animals were dewormed before fattening. Diseases and seasonal price flacuations are identified as rick factors hindering profit made from cattle fattening. However, indigenous breeds have capacity to cope up with harsh environmental conditions, like disease, heat and poor quality feeds [8].

This value is comparable with weight gain of Boran oxen while reasonably higher weight changes compared to other breeds (Bassa et al., 2016). The weight gain of local animals varies based on quality feeds, disease control and other inputs provision [8].

\section{Pattern of weight changes}

A trend of weight in both locations is indicated in Table 3. Initial weight was not signficatnly varied across locations while from thirteen day to final weight varied singifcantly across locations. On thirteen day, $45^{\text {th }}, 60^{\text {th }}, 75^{\text {th }}$ and $90^{\text {th }}$ days oxen at Kachabira was significantly $(p<0.05)$ higher compared to Lemu. The mean finishing weight was $354 \mathrm{~kg} / \mathrm{head}$ and was consistently increased. There is an increasing trend in weight gain across locations; the increaemnt rate being higher in Kachabira compared with Lemu district.

\section{Profitability of fattening business}

Purchase prices, sold amount (birr) and differences due to fatteing is presented in Table 4. On average, the initial purchase price was about 10115.63 Ethiopian birr (ETB) while the average sale price was 18743.85 ETB.

\begin{tabular}{|c|c|c|c|c|c|}
\hline Parameters & Lemu (Hadiya) & Kachabira (KT) & Mean & SE & Sign level \\
\hline Initital weight & 263.84 & 283.95 & 272.8 & 8.9 & $0.1423(\mathrm{NS})$ \\
\hline Weight changes $(\mathrm{kg})$ & 65.41 & 100.63 & 81.06 & 6.47 & $0.0009(* * *)$ \\
\hline Final weight $(\mathrm{kg})$ & 328.25 & 384.58 & 353.8 & 12.38 & $<0.001(* * *)$ \\
\hline Average daily gain (g/head/day) & 0.73 & 1.12 & 0.90 & 0.07 & $0.0009(* * *)$ \\
\hline
\end{tabular}

Table 2: Average daily gain and live weight changes $(\mathrm{kg})$ in selected districts of central South zones, southern Ethiopia.

Mean weight in a row with different superscript letters are statistically different. $* * * \mathrm{P}<0.001$; NS, non-significant; KT, Kembata Tembaro zone.

\begin{tabular}{|c|c|c|c|c|c|}
\hline Parameters & Lemu & Kachabira & Mean & SE & Sign level \\
\hline Initital weight & 263.84 & 283.95 & 272.8 & 8.9 & $0.1423(\mathrm{NS})$ \\
\hline Thirteen day & $240.01^{\mathrm{a}}$ & $299.82^{\mathrm{b}}$ & 266.6 & 10.85 & $0.0008(* * *)$ \\
\hline $45^{\text {th }}$ day & $249.64^{\mathrm{a}}$ & $325.31^{\mathrm{b}}$ & 283.3 & 10.75 & $<0.001(* * *)$ \\
\hline $60^{\text {th }}$ day & $243.73^{\mathrm{a}}$ & $348.95^{\mathrm{b}}$ & 290.5 & 10.70 & $<0.001(* * *)$ \\
\hline $75^{\text {th }}$ day & $247.40^{\mathrm{a}}$ & $365.56^{\mathrm{b}}$ & 294.5 & 14.92 & $<0.001(* * *)$ \\
\hline $90^{\text {th }}$ day & $328.25^{\mathrm{a}}$ & $384.58^{\mathrm{b}}$ & 353.8 & 12.38 & $<0.001(* * *)$ \\
\hline
\end{tabular}

Table 3: Weekly weight change $(\mathrm{kg})$ trends in selected districts of central South zones, Southern Ethiopia.

Mean weight in a row with different superscript letters are statistically different. $* * * \mathrm{P}<0.001$; NS, non-significant. 
Citation: Gemiyo D, Bassa Z, Alemu T (2021) Demonstration and Evlauation of Enset Corm (Ensete venrticosum) Based Oxen Fattening in Kachabira and Lemu Districts, Southern Ethiopia. J Agron Agri Sci 4: 029.

\begin{tabular}{|c|c|c|c|}
\hline Code \# & Purchase & Sold & Net difference \\
\hline & \multicolumn{3}{|c|}{ Kachabora } \\
\hline Code \#1* & 10350.00 & 16000.00 & 5650.00 \\
\hline$\# 2$ & 7500.00 & 15500.00 & 8000.00 \\
\hline$\# 3$ & 4500.00 & 7000.00 & 2500.00 \\
\hline$\# 4$ & 9500.00 & 17000.00 & 7500.00 \\
\hline$\# 5$ & 8000.00 & 16000.00 & 8000.00 \\
\hline$\# 6$ & 12000.00 & 19000.00 & 7000.00 \\
\hline$\# 7$ & 7000.00 & 13500.00 & 6500.00 \\
\hline$\# 8$ & 13000.00 & 20000.00 & 7000.00 \\
\hline$\# 9$ & 11000.00 & 18000.00 & 7000.00 \\
\hline$\# 10$ & 13000.00 & 21000.00 & 8000.00 \\
\hline$\# 11$ & 6000.00 & 14000.00 & 8000.00 \\
\hline$\# 12$ & 15000.00 & 28000.00 & 13000.00 \\
\hline$\# 13$ & 7500.00 & 16500.00 & 9000.00 \\
\hline$\# 14$ & 16000.00 & 29000.00 & 13000.00 \\
\hline$\# 15$ & 9500.00 & 16000.00 & 6500.00 \\
\hline$\# 16$ & 12000.00 & 19000.00 & 7000.00 \\
\hline Mean & 10115.63 & 17843.75 & 7728.13 \\
\hline Max & 16000.00 & 29000.00 & 13000.00 \\
\hline Min & 4500.00 & 7000.00 & 2500.00 \\
\hline
\end{tabular}

Table 4: Market prices and profitability of fattened oxen in Kachabira and Lemu (Averaged), Southern Ethiopia.

Code $\# 1$...represents participants involved in the demonstration, as they fattened an ox, participants number is equal to number of oxen, ${ }^{*}$ farmers who fatten the ox under similar management pooled (averaged) together.

The total amount of concentrate mixture fed to trial animals was $1680 \mathrm{~kg}$, which is about 1500 and other family costs were estimated to be 1228.13 ETB. Thus, $7728.13-1500=5000$, that means smallholder farmers who feed two animals in one fattening period (90 days) using locally available feeds and supplements the animals with enset corm could obtain over 10,000 ETB and minimum of 5000 ETB.

\section{Conclusion}

The overall mean weight (354 kg/head) and the overall gain ( $900 \mathrm{~g}$ /head/day), averaged by locations, is generally and reasonably higher and implies that smallholder farmers could plan supplementation of enset corm for finishing animals in enset dominant farming system. It could also be concluded that supplementing oxen with about $500 \mathrm{gm}$ DM enset corm /head/day along with the available local feeds could help fattening oxen in enset dominant farming systems.

\section{References}

1. CSA (CENTRAL STATISTICAL AGENCY) (2017) Agricultural Sample Survey Volume II report on livestock and livestock characteristics (private peasant holdings) Addis Ababa Ethiopia Group July 2010 working across borders, CENTRAL STATISTICAL AGENCY, Addis Ababa, Ethiopia.

2. Asfaw N, Shahidur R, Birhanu G (2011) Livestock production and marketing Development strategy and Govermenet Division International Food Policy Research. Institute of Ethiopia Strategy Support Program, Ethiopia.

3. Birhanu G, Hoekstra G, Samson Jemanehe (2007) Heading towards commercialization? The case of live animals marketing in Ethiopia. Internaitonal Livestock Research Institute, Kenya.

4. Pavanello Sara (2011) Working across borders: Harnessing the potential of cross-border activities to improve livelihood security in the Horn of Africa drylands. Humanitarian Policy Group, UK.

5. Haile A, Ayalew W, Kebede N, Dessie T, Tegegne A (2011) Breeding strategy to improve Ethiopian Boran cattle for meat and milk production. International Livestock Research Institute, Kenya.

6. Wolde S, Bassa Z, Alemu T (2014) Assessement of cattle fattening and marketing system and constraints affecting cattle fattening in central south region of Ethiopia. African Journal of Agricultural Research 9: 3050-3055.

7. Zekarias B, Wolde S, Alemu T, Yilma M, Terra A, et al. (2016) Evaluation of Locally Available Energy Source Feeds on Fattening Performance of Local Oxen and Carcass Analysis in Wolaita, Southern Ethiopia. Hydrology Current Research 7: 255.

8. Azage T, Birhanu D, Hoeskstra D (2010) Livestock input supply and service provision in Ethiopia: Challenges and opportunities for Market oriented development. International Livestock Research Institute, Kenya. 


\section{Hif}

Advances In Industrial Biotechnology | ISSN: 2639-5665

Advances In Microbiology Research | ISSN: 2689-694X

Archives Of Surgery And Surgical Education | ISSN: 2689-3126

Archives Of Urology

Archives Of Zoological Studies | ISSN: 2640-7779

Current Trends Medical And Biological Engineering

International Journal Of Case Reports And Therapeutic Studies | ISSN: 2689-310X

Journal Of Addiction \& Addictive Disorders | ISSN: 2578-7276

Journal Of Agronomy \& Agricultural Science | ISSN: 2689-8292

Journal Of AIDS Clinical Research \& STDs | ISSN: 2572-7370

Journal Of Alcoholism Drug Abuse \& Substance Dependence | ISSN: 2572-9594

Journal Of Allergy Disorders \& Therapy | ISSN: 2470-749X

Journal Of Alternative Complementary \& Integrative Medicine | ISSN: 2470-7562

Journal Of Alzheimers \& Neurodegenerative Diseases | ISSN: 2572-9608

Journal Of Anesthesia \& Clinical Care | ISSN: 2378-8879

Journal Of Angiology \& Vascular Surgery | ISSN: 2572-7397

Journal Of Animal Research \& Veterinary Science | ISSN: 2639-375

Journal Of Aquaculture \& Fisheries | ISSN: 2576-5523

Journal Of Atmospheric \& Earth Sciences | ISSN: 2689-8780

Journal Of Biotech Research \& Biochemistry

Journal Of Brain \& Neuroscience Research

Journal Of Cancer Biology \& Treatment | ISSN: 2470-7546

Journal Of Cardiology Study \& Research | ISSN: 2640-768X

Journal Of Cell Biology \& Cell Metabolism | ISSN: 2381-1943

Journal Of Clinical Dermatology \& Therapy | ISSN: 2378-8771

Journal Of Clinical Immunology \& Immunotherapy | ISSN: 2378-8844

Journal Of Clinical Studies \& Medical Case Reports | ISSN: 2378-880

Journal Of Community Medicine \& Public Health Care | ISSN: 2381-1978

Journal Of Cytology \& Tissue Biology | ISSN: 2378-9107

Journal Of Dairy Research \& Technology | ISSN: 2688-9315

Journal Of Dentistry Oral Health \& Cosmesis | ISSN: 2473-6783

Journal Of Diabetes \& Metabolic Disorders | ISSN: 2381-201X

Journal Of Emergency Medicine Trauma \& Surgical Care | ISSN: 2378-8798

Journal Of Environmental Science Current Research | ISSN: 2643-5020

Journal Of Food Science \& Nutrition | ISSN: 2470-1076

Journal Of Forensic Legal \& Investigative Sciences | ISSN: 2473-733X

Journal Of Gastroenterology \& Hepatology Research | ISSN: 2574-2566
Journal Of Genetics \& Genomic Sciences | ISSN: 2574-2485

Journal Of Gerontology \& Geriatric Medicine | ISSN: 2381-8662

Journal Of Hematology Blood Transfusion \& Disorders | ISSN: 2572-2999

Journal Of Hospice \& Palliative Medical Care

Journal Of Human Endocrinology | ISSN: 2572-9640

Journal Of Infectious \& Non Infectious Diseases | ISSN: 2381-8654

Journal Of Internal Medicine \& Primary Healthcare | ISSN: 2574-2493

Journal Of Light \& Laser Current Trends

Journal Of Medicine Study \& Research | ISSN: 2639-5657

Journal Of Modern Chemical Sciences

Journal Of Nanotechnology Nanomedicine \& Nanobiotechnology | ISSN: 2381-2044

Journal Of Neonatology \& Clinical Pediatrics | ISSN: 2378-878X

Journal Of Nephrology \& Renal Therapy | ISSN: 2473-7313

Journal Of Non Invasive Vascular Investigation | ISSN: 2572-7400

Journal Of Nuclear Medicine Radiology \& Radiation Therapy | ISSN: 2572-7419

Journal Of Obesity \& Weight Loss | ISSN: 2473-7372

Journal Of Ophthalmology \& Clinical Research | ISSN: 2378-8887

Journal Of Orthopedic Research \& Physiotherapy | ISSN: 2381-2052

Journal Of Otolaryngology Head \& Neck Surgery | ISSN: 2573-010X

Journal Of Pathology Clinical \& Medical Research

Journal Of Pharmacology Pharmaceutics \& Pharmacovigilance | ISSN: 2639-5649

Journal Of Physical Medicine Rehabilitation \& Disabilities | ISSN: 2381-8670

Journal Of Plant Science Current Research | ISSN: 2639-3743

Journal Of Practical \& Professional Nursing | ISSN: 2639-568

Journal Of Protein Research \& Bioinformatics

Journal Of Psychiatry Depression \& Anxiety | ISSN: 2573-0150

Journal Of Pulmonary Medicine \& Respiratory Research | ISSN: 2573-0177

Journal Of Reproductive Medicine Gynaecology \& Obstetrics | ISSN: 2574-2574

Journal Of Stem Cells Research Development \& Therapy | ISSN: 2381-2060

Journal Of Surgery Current Trends \& Innovations | ISSN: 2578-7284

Journal Of Toxicology Current Research | ISSN: 2639-3735

Journal Of Translational Science And Research

Journal Of Vaccines Research \& Vaccination | ISSN: 2573-0193

Journal Of Virology \& Antivirals

Sports Medicine And Injury Care Journal | ISSN: 2689-8829

Trends In Anatomy \& Physiology | ISSN: 2640-7752

Submit Your Manuscript: https://www.heraldopenaccess.us/submit-manuscript 